\title{
Impact of Coastal Pollution on Childhood Disabilities and Adverse Pregnancy Outcomes: The Case of Bangladesh
}

\author{
Juma Rahman', Nitaya Vajanapoom², Marc Van Der Putten ${ }^{3}$ and Nafeesur Rahman ${ }^{4}$ \\ ${ }^{1}$ Faculty of Public Health (Global Health), Thammasat University, PO box 12120, Pathum Thani, Thailand. \\ ${ }^{2}$ Assoc. Professor. Vice Dean for academic: Epidemiology. Faculty of Public Health. Thammasat University, PO box 12120, Pathum Thani, Thailand. \\ ${ }^{3}$ Assoc. Professor. Asst. Dean International Affairs. Faculty of Public Health. Thammasat University, PO box 12120, Pathum Thani, Thailand. \\ ${ }^{4}$ Director, National Forum of Organizations Working with the Disabled (NFOWD), Lalmatia, PO box 1207, Dhaka, Bangladesh.
}

\section{A B STRACT}

Objective: The objective of this review was to explore the situation of coastal water pollution and its impact on child health and pregnancy outcomes in Bangladesh. Background: Globally coastal pollution is of greater significance than inland's for its huge resources and contribution to livelihood. As a result it has been a source of increased Global Burden of Disease by means of consumption of seafood, involvement in risky jobs, and exposure to water related disastrous events. Almost sixty percent of the world's population is at risk of costal contamination and developing countries like Bangladesh, geographically located at the tip of the Bay of Bengal, are facing significant challenges by this form of pollution. Method: This study was based on a critical review of published literature and unpublished documents from 1972 to 2011 retrieved from databases of scientific publications, from public-access search engines, reports from government, international organizations, and non-government agencies, and personal communications. Discussion: Huge noxious pollutants including heavy metals, oil spill and redionucleotides were found in the Bay of Bengal, those have enormous adverse impacts on child health and pregnancy outcomes. This review focuses on children and pregnant women because of their vulnerable physiological conditions to the impacts of environmental factors. The physiological systems of children and fetuses are developing fast and usually are sensitive to disruptions induced by environmental pollutants and exposures in utero increase the risk of future toxic insults. Conclusion: The coastal zone of Bangladesh is one of the vulnerable zones in the world which is predicted to disappear due to climate change impacts. This areas face huge weather-related disasters due to continuous changing coastal-configuration and man-made pollutions. However, these observations are indecisive due to limitations of supportive evidence. Therefore, further epidemiological studies are required to confirm initial observations.

Keywords: Coastal pollution, Coastal zone, heavy metal, persistent organic pollutants, childhood disability, adverse pregnancy outcome

\section{INTRODUCTION}

This study describes to what extend children and pregnant women living in coastal zones of Bangladesh are exposed to selected pollutants, and discuss evidenced health hazards and risks faced by this vulnerable segment of the population. The review assisted in compiling the lessons learnt from the literature with the aim to contribute to

\footnotetext{
*Address for correspondence:
}

E-mail: jumarahman@gmail.com

DOI: 10.5530/ijmedph.2.3.4 decision-making on both mitigation and preventive measures to protect coastal population in Bangladesh.

The objectives were to review evidence of coastal water pollutions in Bangladesh, focusing on heavy metals, chemicals and radioactive pollutants' exposure to explore the impacts of these pollutants on child health and pregnancy outcomes in the coastal Bangladesh. Presently, evidence on this issue is lacking, indicating a need to investigate the links between coastal water pollutions and adverse health impacts of the population residing in its coastal area. A better understanding of these issues would be of use for future public health practice in Bangladesh. 
The health and well being of the individuals and populations could be affected at different levels by anthropogenic and natural factors of coastal pollution including: harmful algal blooms, microbes, and chemical pollutants in oceans; consumption of seafood; involvement in risky jobs and offshore flooding events. Coastal pollution is drawing global attention due to its transboundary issues and threat to huge coastal communities (globally the population density in coastal zones is 2.6 times greater than inland). ${ }^{1}$ Almost sixty percent of the world's population, i.e. 3 billion people (live on or within $100 \mathrm{~km}$ of a sea coast) has to face huge health-related effects from coastal pollution. ${ }^{2}$

The United Nation defines coastal pollution as the introduction by man, of substances or energy to the marine environment, directly or indirectly, resulting in deleterious effects such as: hazards to human health, hindrance to marine activities, impairment of the quality of seawater for various uses and reduction of facilities. ${ }^{3}$ It was estimated that globally 10,000 million gallons of sewage, 3.25 million metric tons of oil, 10 billion tons of ballast water and millions of tons of solid waste are discharged into the marine environment per annum. ${ }^{4-5}$ Furthermore, industrial untreated wastes are contributing to the "coastal dead zone" (i.e. insufficient oxygen level to support marine life) extension and constant heavy metal contamination to sea food. Almost $70 \%$ industrial discharges and $85 \%$ of waste water are discharged untreated from developing countries. For instance, annually more than 600,000 tonnes of nitrogen is delivered into the Indian Ocean, while 17 tonnes of mercury and nearly 150 tonnes of cadmium are discharged into the Caspian Sea. ${ }^{6-7}$ Figure 1 shows the distribution across global regions of the ratio of treated and untreated wastewater reaching seas and oceans; where it is found that $80 \%$ to nearly $90 \%$ of sewage entering coastal waters to be raw and untreated, originate mostly from

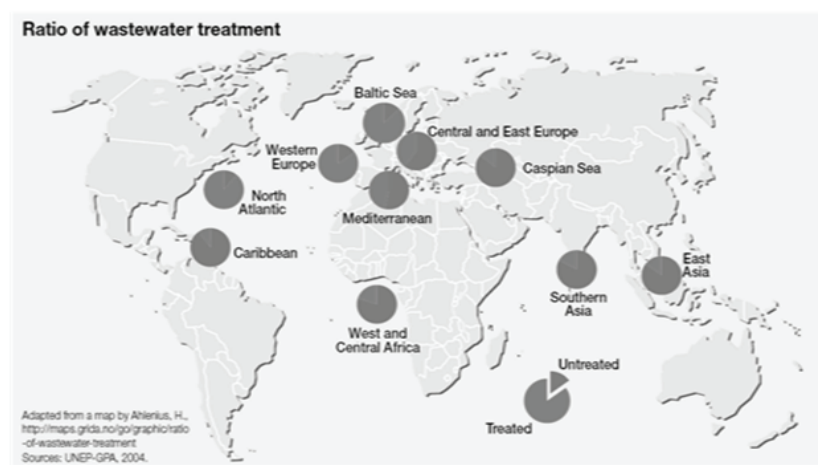

Figure 1. The global map showing the ratio of treated and untreated wastewater reaching water bodies for 10 regions. Source (UNEP, 2006). developing countries ${ }^{5}$ including countries of the Indian Ocean rim, East Africa, the Arabian Peninsula and South and Southeast Asia. Furthermore besides weapon test 85 petabecquerel radioactive substances were dumped in the ocean (80 locations worldwide) intentionally over the period of 30 years. ${ }^{8}$

Heavy metal poisoning on human health first received attention in Japan in 1912, when cadmium was found as a causative agent of acquired Fanconi Syndrome, that is renal tubular dysfunction (kidney failure) and osteomalacia (softening of bone) with severe pain in the bones. The disease is known as Itai-itai Byo (Japanese; Itai means pain). ${ }^{79}$ Again in 1956, Minamata disease was discovered at Minamata city in Kumamoto industrial prefecture, Japan, due to mercury poisoning in the downstream water. Manifestations of Minamata disease are numbness of limbs, difficulties in moving hands and legs, tremor of hands, hearing difficulties, speech disorder, visual field constriction, distortion of sense of equilibrium and finally people become insane leading to death. Later on a considerable number of children with conditions resembling cerebral palsy were born in the exposed areas of Japan. ${ }^{10}$

Since then a large number of studies were conducted worldwide. Among them the 14 years cohort study at the Faroese Island by Philippe Grandjean is worth to mention. In this cohort study, a cohort of 1022 singleton births was assembled from the Faroese Islands and the study demonstrated that prenatal exposure to mercury (Methyl mercury), by maternal consumption of contaminated sea food, can lead to cognitive deficit in their children, with more pronounced manifestations in the domains of speech, attention, memory and delayed cardiac activity in children. ${ }^{11-12}$

Furthermore, there are some studies that suggest causal relation of Autistic Spectrum Disease with the mercury poisoning in children due to prenatal exposure. For instance children with autism had a 2-time higher level of mercury in their baby teeth and excrete 3.1 times higher mercury $(\mathrm{P}<.0002)$ into their urine. ${ }^{13}$

Moreover, recently lead exposure has been found connected to ocular neuritis in children which may lead to visual impairment or complete loss of vision. ${ }^{14}$ Researchers found that lead causes increased intracranial pressure which directly irritates the optic nerve, a condition known as "ocular plumbism" believed to be due to swelling rather than inflammation. This may contribute to strabismus (a condition in which the eyes do not point in the same direction), and consequently, double vision. $^{15}$ 


\begin{tabular}{|c|c|c|}
\hline Location & PHC & References \\
\hline Abu Dhabi,UAE & $6.14-62.7$ & Abd et al. 2008 \\
\hline Arabian Gulf & $5.4-92.0$ & Al-Lihaibi and Ghazi, 1997 \\
\hline Arabian Sea along the Indian coast & $0.6-5.8$ & Sengupta et al. 1993 \\
\hline Bassein-Mumbai coast, India & $7.0-38.2$ & Chouksey et al. 2004 \\
\hline Bizerte lagoon, Tunisia & $0.05-19.5$ & Mzoughi et al. 2005 \\
\hline Changjiang estuary, China & $2.2-11.82$ & Bouloubassi et al. 2001 \\
\hline Fraser River Basin,Canada & $1.6-20.6$ & Yunker and Macdonald Robie, 2003 \\
\hline Gulf of Fos, France & $7.8-180$ & Mille et al. 2007 \\
\hline Jiaozhou Bay, China & $0.54-8.12$ & Wang et al. 2006 \\
\hline Shetland Island, UK & $7.0-8,816$ & Kingston et al. 1995 \\
\hline Straits of Johor, Malaysia & $0.7-36.7$ & Abdullah et al. 1996 \\
\hline Tamilnadu coast, India & $1.48-4.23$ & Veerasingam et al. 2010 \\
\hline Thane Creek, India & $7.6-42.8$ & Chouksey et al. 2004 \\
\hline Chennai coast, India & $1.8-39.72$ & Venkatachalapathy, 2010. \\
\hline
\end{tabular}

Source: (Venkatachalapathy, 2010).

Other heavy metals like arsenic and lead also have adverse impacts on development of the brain in fetuses and pregnancy outcome. Although arsenic is mostly a natural pollutant for some countries like Bangladesh, India, and Nepal; there are many industrial effluents (e.g. from tanneries and ship breaking) that contain significant amounts of arsenic, cadmium and lead, and can be consumed by sea foods as well (e.g. shrimps and finfish). Prenatal exposure of these metals can cause adverse pregnancy outcomes like spontaneous abortion, still birth, low birth weight, prematurity and early neonatal death. ${ }^{16-22}$

A cross-sectional community based study in Punjab showed that spontaneous abortion and premature births were significantly higher $(\mathrm{p}<0.05)$ and stillbirths were five times higher in area affected by heavy metal and pesticide pollution. ${ }^{23}$ Again mercury concentration in urines of fathers above 50 micrograms/1 increased the risk of spontaneous abortion (OR $=2.26 ; 95 \%$ confidence interval $=0.99-5.23) \cdot{ }^{24}$

Also Persistent Organic Pollutants are well known to cause reproductive disorders as well as cancerous cells' growth in human when exposed to polluted beach.
Moreover significant health impacts from pharmaceutically active products from medical wastes, such as ingredients of birth control pills and of anti-depressant and anti inflammatory medications may lead to unidentified chronic health effects in humans when consumed through sea foods. ${ }^{25}$

Polycyclic Aromatic Hydrocarbons (PAHs) are also well known genotoxic chemical pollutants. A study of the meconium of 135 newborns with congenital heart disease and 432 newborns without congenital heart disease showed $82 \%$ having evidence of intrauterine exposure to chemicals of crude oil. It can cause sperm dysplasia as well, leading to chromosomal abnormalities in future generations. ${ }^{26-27}$ Table 2 shows the critical review of comparison of Petroleum Hydrocarbon in sediment of selected marine areas by Venkatachalapathy. ${ }^{28}$

Finally enormous carcinogenic and genotoxic effects of radioactive substances were described in the literature. These substances remain radioactive for thousands of years in the entire environment and are responsible for childhood disability mostly with adverse pregnancy outcomes. $^{8}$

\section{Table 2: Metal Concentrations at Shitakunda Area (near ship break yard) measured in ppm = parts per million}

\begin{tabular}{lccc}
\hline Name of the Metals & $\begin{array}{c}\text { Concentration } \\
\text { (MoEF, 2004) }\end{array}$ & $\begin{array}{c}\text { Concentration } \\
\text { (World bank, 2010) }\end{array}$ & Bangladesh Quality Standards \\
\hline Lead & $0.5-21.8$ & $11.3-197.7$ & 0.05 \\
Chromium & 220 & $2.42-22.12$ & 0.05 \\
Cadmium & $0.3-2.9$ & $0.6-2.2$ & 0.005 \\
Iron & $2.6-5.6$ & NA & 1.0 \\
Mercury & NA & $0.078-0.158$ & NA \\
Oil & NA & $485-4430$ & NA
\end{tabular}

* NA = Not Available

Source: (MoEF, 2004). 


\section{METHODS}

STUDY AREA: The coastal zone of Bangladesh demarcated by the Integrated Coastal Zone Management Project (ICZMP) of Water Resources Planning Organization (WARPO) of the Bangladesh Government has been adopted for this study, which comprises of 47,201 sq $\mathrm{km}$ of areas including nineteen districts (provinces) of four divisions (regions). These are: Barguna, Bhola, Barisal, Jhalkathi, Patuakhali, Pirojpur of Barisal division; Bagerhat, Jessore, Khulna, Narail, Satkhira of Khulna division; Chandpur, Chittagong, Cox's Bazaar, Feni, Lakshmipur, Noakhali of Chittagong division; and Gopalgonj and Shariatpur of Dhaka division. ${ }^{29}$

More precisely Barisal division is wholly a coastal area; Khulna's five out of ten districts are coastal areas, whereas six of eleven districts in Chittagong and two of seventeen districts in Dhaka are included into coastal zone. Figure 2 shows the map of the coastal zone which is divided into exposed coast (black color), and interior coast (grey color).

STUDY POPULATION: According to Child Abuse Prevention and Treatment Act (CAPTA) and Individuals with Disabilities Education Act (IDEA) Sec 602 (3), the term 'child with a disability' applied for a child aged 3 to 9 years, who are: (i) experiencing developmental delays, as measured by appropriate diagnostic instruments and procedures, in one or more of the following areas: physical development; cognitive development; communication development; social or emotional development; or adaptive development; and (ii) by reason thereof, are in need of special education and related services. ${ }^{30}$

Informed by the above, children of three to nine years and pregnant women of the coastal zone were adopted for this review on adverse pregnancy outcomes (e.g.

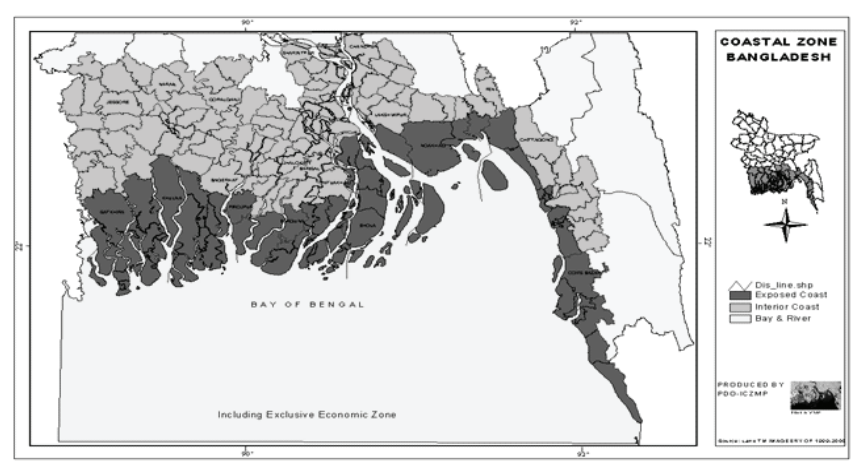

Figure 2. Map of the coastal zone of Bangladesh. Source: (MoWR, 2006). low birth weight, premature birth, intra uterine growth retardation, still birth, miscarriage, early neonatal death, congenital anomaly).

SEARCH STRATEGY: Published literature and unpublished documents from 1972 to 2011 were searched from World Health Organization, Multiple Indicators of Cluster Survey-UNICEF, Bangladesh Ministry of Health and Family Welfare, Directorate General of Health Service, Bangladesh Bureau of Statistics, Demography and Health Survey and Bangladesh Metrological Department. Published articles were searched from databases such as PubMed, Springerlink, ScienceDirect, Environment Journals, Springer, OVID, Google Scholar and Google web.

Boolean search queries using following keywords were: "Marine pollution" OR "Coastal Water pollution" AND "Seafood poisoning", AND "Oil spill hazards", AND "Radioactive substances", AND "Ship breaking industries", AND "Human health hazard", AND "Water quality of Bangladesh", AND "Maternal and Child Health of Bangladesh".

REFERENCE MANAGEMENT: The articles reviewed were restricted to those published in English and Bengali languages only. A list of materials retrieved by the search was created and materials were reviewed and documents marked which included relevant information. Marked materials were then reviewed in-depth to determine and/ or confirm initial identified relevance. Unmarked items were then reviewed to determine their relevance and finally a list of marked materials was created in APA/ Vancouver format using Endnote to serve a matrix based systematic review.

\section{RESULT}

EVIDENCES OF POLLUTION OF THE BAY OF BENGAL: Bay of Bengal is the drainage basin of eleven countries, including India, Nepal, Bhutan, Tibet of China, Bangladesh, Myanmar, Sri Lanka, Maldives, Malacca Straits of Indonesia (Sumatra), western Peninsular Malaysia, and the western part of southern Thailand (Bay of Bengal Sub Region-BOBSR). ${ }^{31}$ And Bangladesh has the down streams of this drainage basin, contaminated with pollutants from Nepal, Bhutan, India and Tibet. In terms of land based pollutants; domestic sewage, industrial effluents, agricultural wastes, and aquaculture all 
contribute to pollution of the marine environment, but sewage is the dominant contributor in the Bay of Bengal sub-region. ${ }^{32-33}$ Besides $90-95 \%$ untreated sewage, nearly $75 \%$ of untreated industrial effluents are discharged into the Bay of Bengal. These effluents contain huge amounts of chemicals and heavy metals. ${ }^{34}$ In most cases, heavy metal contamination is localized near the source, the exceptions are the volatile metals lead and mercury, that can be transported long distances in the atmosphere with the most lethal effects. ${ }^{33,35}$

In the Bay of Bengal major sea-based pollutions are related to ship breaking, oil spill and oil exploration. In India $75 \%$ and Bangladesh $60 \%$ of ships are dismantled without any environmental precautions. The entire scrapping process is done manually by unskilled laborers which intensifies the risk. By this process, a ship usually discharges 10 to 100 tons of heavy metals and chemical substances such as: paint containing lead, mercury, cadmium, chromium and arsenic; zinc; thousand liters of oil and chemicals like- PAHs; tributyltin; organotins; sealants containing polychlorinated biphenyls (PCBs) and asbestos. These pollutants are dumped into the sea water openly. ${ }^{36}$ And the scraps from ships are kept haphazardly allowing trace metal contamination to beach soil which can be mixed with the surface, ground water and coastal water during coastal floods or astronomical tide. ${ }^{6,37}$

Recently (2010) the World Bank measured heavy metal concentrations in the sediments near ship breaking yards and the Ministry of Environment and Forest (MoEF) did the same in 2004. The results shown in Table 2 indicate that the concentrations of major noxious heavy metals are changing and exceed the Bangladesh quality standard (EQS) near ship breaking yards. ${ }^{38}$

Coastal Bangladesh is mainly an industrial area. According to statistics of 2000 of the Mongla export processing zone (EPZ), there were a total of 18 industries in this industrial belt. Moreover, around 40 industries were situated within the Mongla EPZ by June, 2001 (1st phase of establishment). Discharges from most of these industries such as tanneries, textile, and paper industries contain huge amount of heavy metals and other chemicals. ${ }^{6,39}$ The Asian Development Bank estimated that in Chittagong, tannery industries discharge nearly 150,000 liters of liquid waste per day while the Government owned Karnaphuly Paper Mill releases 0.35 tons of China clay everyday into the Bay of Bengal without minimal degree of treatment. ${ }^{40-41}$

Further, it is important to note that most of the solid waste landfill areas are near the shore. As a result, toxic substances from solid waste will contaminate soil and water, and subsequently enter into the food chain by sea foods and by grains cultivated in the contaminated soil. ${ }^{16}$ Table 3 shows the main grains of Bangladesh containing significant amounts of heavy metals cultivated in contaminated soil.

Heavy metals like arsenic, lead, and cadmium are also found in vegetables of Bangladesh such as okra (also known as ladies finger), potato, eggplant, papaya, winter melon and snake gourd, cultivated in heavy metal contaminated soil by long term irrigation with contaminated water. $^{18}$

Chemicals like petroleum hydrocarbon are also common in the Bay of Bengal. Almost every year, oil spill incidents occur in the Strait of Malacca, Riau Islands of Indonesia, which is the main source of oil spill in the Bay of Bengal besides discharged by ships/fishing trawlers. The major transboundary coastal pollution issues are oil pollution and hazardous waste carried and discharged by vessels. ${ }^{42}$ In addition to oil spill and heavy metal, radionucleotides are also found in the Bay of Bengal, released from offshore power plants. There is a huge power plant located at the Chennai coastal zone, close to Bangladesh, routinely tritium is released from the reactor through atmospheric and liquid discharge routes and contaminating the Bay of Bengal Sub-region. ${ }^{34}$

Bangladesh is situated at the conical northern tip of Bay of Bengal, with some additional vulnerable factors such

\begin{tabular}{|c|c|c|c|c|c|c|c|}
\hline \multirow[t]{2}{*}{ Heavy Metal } & \multicolumn{3}{|c|}{ Wheat } & \multicolumn{3}{|c|}{ Rice } & \multirow[t]{2}{*}{ Permissible limit in grain } \\
\hline & Root & Shoot & Grain & Root & Shoot & Grain & \\
\hline $\mathrm{Cr}$ & 376 & 5.4 & $<5$ & 4702 & 112 & $<5$ & 2.83 \\
\hline $\mathrm{Cu}$ & 9.9 & 4.2 & 9.7 & 4.0 & 6.3 & 4.3 & 1.36 \\
\hline $\mathrm{Mn}$ & 19 & 10 & 15 & 161 & 125 & 34 & $N A^{*}$ \\
\hline $\mathrm{Zn}$ & 129 & 57 & 118 & 276 & 121 & 03 & $9.43-15.78$ \\
\hline
\end{tabular}

*NA $=$ Not Available.

Source: (Huq, 1998) 


\begin{tabular}{|c|c|c|c|c|c|c|}
\hline Disabilities & Khulna & Chittagong & Barisal & Dhaka & Rajshahi & Sylhet \\
\hline Hearing & 22.9 & 19.3 & 13.5 & 18.2 & 19.1 & 21.0 \\
\hline Visual & 19.3 & 31.2 & 39.1 & 36.4 & 31.2 & 29.0 \\
\hline Speech & 1.2 & 7.5 & 3.8 & 4.5 & 3.5 & 2.0 \\
\hline Physical & 38.6 & 30.1 & 26.3 & 22.7 & 27.0 & 29.0 \\
\hline Intellectual & 8.4 & 2.2 & 3.8 & 8.5 & 5.7 & 6.0 \\
\hline
\end{tabular}

Source: (Titumir \& Hossain, 2005)

as; its long-funnel shaped continental shelf, shallow and wide bathymetry, complex coastal geometry with many kinks and islands, high astronomical tides and long tidal range between east and west coasts allow almost five tropical storms with highest storm surge to drive each year. During storms, cyclones, and hurricanes coastal flood brings immeasurable pollutants to its land area and contaminates surface water, ground water and agricultural fields. Even high astronomical tide (1 $\mathrm{m}$ without any impact of climate change or sea level rise) comes twice daily. Literature indicates that $0.21-0.48 \mathrm{~m}$ sea level rise can expose 11,000-25,000 cubic meters of contaminated sand in the Chittagong shoreline. ${ }^{37,43-44}$

The above presented evidence indicate the extreme pollution of the Bay of Bengal and it has been projected that large amounts of hazardous materials are likely to accumulate in Bangladesh if the prevailing practices continue over the next 20 years. ${ }^{39}$

\section{EVIDENCES OF CHILDHOOD DISABILITY AND PREGNANCY OUTCOME IN BANGLADESH: In Bangladesh no regular} national disability prevalence survey is conducted by the national statistical agency, Bangladesh Bureau of Statistics. Some Government surveys in 1982, 1986 and 1998 estimated the national prevalence rates of disability at $0.64 \%, 0.05 \%$ and $1.60 \%$ of the total population respectively. ${ }^{(45)}$ The reliability of these data is conspicuous since it is expected to have an increasing trend. However another prevalence survey of childhood neurodisabilities showed prevalence of $6.8 \%$ in 1988 and $17.65 \%$ in $2001 .{ }^{46}$

The location aspect of the disability prevalence in coastal divisions (regions) showed physical (45.2 percent), speech and hearing (both at 11.3 percent), and visual impairments (24.2 percent) as the most pronounced although no statistical significance was described in the report. A geographical distribution of the above mentioned disabilities is presented in Table $4 .^{45}$

Table 5 summarizes the findings on division-wise pregnancy outcomes of a survey (2003-2004) by Haseen ${ }^{47}$ on low birth weight. Although this data should be treated with vigilance because the last menstrual period dates of most of the women in Bangladesh were not known with accuracy and were estimated. ${ }^{47}$ Other adverse pregnancy outcomes related data were lacking or incomplete.

\section{DISCUSSION}

There is no universal consented definition of a coastal zone. Particularly in terms of how far inland coastal zones reach, and it has been demarcated in various ways for the purposes of coastal zone management. In Bangladesh several parameters were adopted by the Water Resources Planning Organization (WARPO) of the Bangladesh Government to delineate its coastal zone. For example administrative units, ecological units, cyclones and storm surges, salinity, and even tidal influences. However, according to the coastal zone policy (CZPo, 2005) of the Government of Bangladesh, 19 districts out of 64 are considered coastal zone covering a total of 147 Upazila (sub-districts). Out of these 19 districts, only 12 districts meet the sea or lower estuary directly, while the remaining districts were included based on a variety of other criteria as described above.

As presented in Table 4, certain neurological impairments are higher in the coastal divisions (in general Khulna, Chittagong and Barisal) of Bangladesh. This higher prevalence in certain disabilities might be related

\begin{tabular}{lccccccc}
\multicolumn{7}{l}{ Table 5: Prevalence of adverse pregnancy outcomes in division (i.e.region) wise (2003-2004) } \\
\hline Pregnancy outcomes & Barisal & Chittagong & Khulna & Dhaka & Rajshahi & Sylhet & National \\
\hline miscarriage & 16 & 10 & 9 & 10 & 10 & 14 & 76 \\
Still birth & 18 & 20 & 24 & 26 & 15 & 62 & 186 \\
Low birth weight (\%) & 38.7 & 28.0 & 35.5 & 43.7 & 37.3 & 37.6 & 35.6 \\
\hline
\end{tabular}

Source: (Haseen, 2006) 
to heavy metal and chemical poisoning since they were found at significant levels in most of the coastal districts. For physical disability, the major disorder was paralysis, which is also a neurological effect. This raises a question about Minamata disease caused by consumption of mercury contaminated sea food. However further studies are required to establish possible associations since the lack of accessibility and availability of district-wise data makes this comparison indecisive.

Based on the data presented in Table 5, divisional variations regarding pregnancy outcome does not provide a clue. Hence it could be assumed that high concentration of health care services accessible for women in Sylhet and Dhaka by NGOs and industries (e.g. garment factories, tea garden estates) contributed to the national health registration and recording system, therefore contributing to divisional variations. Another possibility of higher low birth weight in Dhaka might be due to a high rate of working mothers and or the presence of extensive urban slums. Although Barisal, which is the only absolute coastal division, showed higher miscarriage rates but this was not significantly higher than Sylhet. Moreover still birth and early neonatal death (in preterm delivery) were sometimes wrongly diagnosed as miscarriage by traditional birth attendants, as $85 \%$ of delivery still take place at home in Bangladesh. ${ }^{48}$ So the reliability of the data raises questions again.

Socio-economic condition in the coastal zones also increases the risk of exposure. The poverty level in coastal areas of Bangladesh is higher: absolute poor households were as high as $52 \% .{ }^{49}$ And poverty may expose coastal residents, especially children, to hazardous pollutants by involving in risky jobs like ship demolition (where most of the laborers are below ten years of age), shell and coral collection from the beach, solid waste separation from the dumping area, and so on. ${ }^{36}$ Young children of poor mothers spend times playing in the Bay water or even in the ship yard while mothers remain busy for livelihood. Moreover coastal fishers' families and deprived people live on sea food mostly. ${ }^{50}$ As such, a large proportion of the poor coastal residents of Bangladesh are continuously exposed to the heavy metals and chemicals of the polluted Bay water.

Again adverse birth outcomes are attributable to various factors. For instance stunted mothers are significantly related to low birth weight infants $(\mathrm{P}<0.001) .{ }^{47}$ Malnutrition is higher among coastal area residents. However, due to lack of district data on malnutrition it is difficult to comment because stunting is higher among tribal people of hilly areas (non-coastal zone) as well which might point to confounding factors contaminating the data of Chittagong. Hence district-wise health data is mandatory to conclude.

Furthermore, cultural norms induced travel restrictions could be another causal factor to pregnancy outcomes and childhood disability. Also the lack of a good road infrastructure often deprives coastal people from health facilities. Prolonged and obstructed labor, critical obstetric conditions, and any emergency condition of new born take longer time to be treated, due to insufficient communication systems and dysfunctional health delivery systems. Such untreated or delayed treated conditions may impact child neurodevelopmental disabilities, but there is no concrete study adjusting these confounding factors as well.

Considering the main effects on human health, global burden is increasing by the means of disability among both child and adult. Literature review shown annually 2.2 to 13.9 billion USD was lost due to loss of child intelligence from heavy metal poisoning in USA. ${ }^{51}$ And globally 11.6 billion USD/year is lost due to consumption of contaminated seafood ( $\$ 4,000 /$ DALY- this includes sea food induced infectious diseases e.g. hepatitis). ${ }^{52}$ Thus heavy metal, chemical and radioactive substances silently contribute to the national/global economical penalties by the means of increasing medical cost and DALY (Disability adjusted Life Years)/YLD (Years Lived with Disability).

\section{CONCLUSION AND RECOMMENDATION}

Bangladesh is one of the over populated and underprivileged countries. Due to its geographical location in the Bay of Bengal, most of the pollutants are deposited by means of coastal flood, storm surges and high astronomical tides. Moreover it is the most densely populated coastal zone (544 persons per sq km living within $100 \mathrm{~km}$ of the coast); with a large portion of the population in the reproductive age (about $50 \%$ of the total population). ${ }^{49,53}$ Therefore, a huge quantity of the population is exposed to coastal pollution each day.

It is obvious that childhood disability is increasing in Bangladesh, probably due to a variety of reasons such as increased air pollution, poverty, decreased accessibility and availability of health services, and so on. A division-wise distribution indicated that coastal divisions (provinces) have higher rates of neurological disabilities 
and impairments compared with inland divisions. These indications raise the question whether there is an association with neurotoxic and genotoxic pollutants. Further study with district-wise data will be required to test such hypothesis.

Moreover improvements of health information systems in Bangladesh are highly recommended. Adverse pregnancy outcomes, likely leading to developmental impairment, needs detailed medical recording. In-depth evaluation not only would provide more reliable data, but could also shed light on likely precursors. Recordings on preterm births also should be given special attention. It is also crucial to have improved disease surveillance systems with better monitoring. In light of these challenges, further welldesigned epidemiological surveillance systems and research on adaptation and mitigation policies are recommended.

The knowledge of industrial waste poisoning is still unknown to the people of many developing countries like Bangladesh, where environmental policies are weak and corrupted. Finally, the health service in Bangladesh is already scarce. Therefore emphasis must be given to education and training of future researchers, awareness raising among policy makers and the general public to change harmful attitudes that contribute to the coastal pollution in Bangladesh.

\section{REFERENCES}

1. Michel D, Pandya A. Coastal zones and Climate change. [Internet] Washington: The Henry L. Stimson Center; 2010 [cited 2011 4th of May]; Available from: www.stimson.org/rv.

2. Klein RJT, Nicholls RJ, Thomalla F. The resilience of coastal megacities to weather-related hazards. 2003 [cited 2011 13th of August]; Available from: www.worldbank.

3. Henry A. Marine Pollution. n.d. [cited 2010 Dec 27]; Available from: www. nepa.gov.jm/student/resource-material/.../Marine_Pollution.pdf

4. Ruiz-Villarreal M, Gonzalez-Pola C, Diaz del Rio G, Lavin A, Otero P, Piedracoba S, et al. Oceanographic conditions in North and Northwest Iberia and their influence on the Prestige oil spill. Mar Pollut Bull. 2006;53(5-7):220-38.

5. UNEP. Concern over oceans despite receding oil \& chemical threats. [Press release] The Hague: UNEP News Center; 2006 [cited 2011 Feb 12]; Available from: web1.unep.org/Documents.Multilingual/Default.asp.

6. Hossain MMM. Ship Breaking Activities and its Impact on the Coastal Zone of Chittagong, Bangladesh: Towards Sustainable Management. Chittagong: Advocacy \& Publication Unit, Young Power in Social Action (YPSA); 2006.

7. UNEP. Interim reviews of scientific information on lead and cadmium. UNEP; 2006 [cited 2011 Sep 23]; Available from: http://www.chem.unep. $\mathrm{ch} / \mathrm{Pb}$ and $\mathrm{Cd} / \mathrm{SR} /$ Interim reviews.htm.

8. A Summary of Facts and Findings on Marine and Coastal Issues in the Wider Caribbean Region [database on the Internet]. UNEP Caribbean Environment Programme. 2008 [cited February, 2012].

9. Friberg L, Piscator M, Nordberg G, Kjellstrom T. Cadmium in the Environment, II. Environmental Health Perspective. 1984;54:1-11.
10. Harada M, Yorifuji T, Tsuda T. Epidemiology of Congenital Minamata Disease Patients. Epidemiology. 2011;22(1):S100.

11. Grandjean P, Weihe P, White RF, Debes F, Araki S, Yokoyama K, et al. Cognitive Deficit in 7-Year-Old Children with Prenatal Exposure to Methylmercury. 1997;19(6):417-28.

12. Grandjean P, Murata K, Budtz-Jørgensen E, Weihe P. Cardiac autonomic activity in methylmercury neurotoxicity: 14-year follow-up of a Faroese birth cohort $^{*}$ 1. The Journal of pediatrics. 2004144(2):169-76.

13. Adams JB, Baral M, Geis E, J. Mitchell, Ingram J, A. Hensley, et al. The severity of autism is associated with toxic metal body burden and red blood cell glutathione levels. Journal of Toxicology. 20092009(532640).

14. Christophers AJ. Paediatric lead poisoning in Queensland: how and why it was so different from paediatric lead poisoning elsewhere. Melbourne: Dept. of Epidemiology \& Preventive Medicine, Monash University; 1999.

15. Gibson JL. Ocular plumbism in children. The British Journal of Ophthalmology. 193115(10):637-42.

16. Critical Environmental Issues Relating to Tanning Industries in Bangladesh [database on the Internet]. ACIAR; 1998. 1998 [cited April,2010]. Available from: http://aciar.gov.au/files/node/319/PRO088\%20part\%202.pdf

17. Khan MAA, Khan YSA. Trace Metal in Littoral Sediments from the North East Coast of the Bay of Bengal along the Ship Breaking Area, Chittagong, Bangladesh. Journal of Biological Science. 20033 (11):1050-7.

18. Alam M, Snow E, Tanaka A. Arsenic and heavy metal contamination of vegetables grown in Samta village, Bangladesh. The Science of the total environment. 2003308(1-3):83-96.

19. Khan I, Hassan S, McEvoy M, D'Este C, Attia J, Peel R, et al. Association Between Type 2 Diabetes and Chronic Arsenic Exposure in Bangladesh. Epidemiology. 201122(1):S154.

20. Meliker JR, Wahl RL, Cameron LL, Nriagu JO. Arsenic in drinking water and cerebrovascular disease, diabetes mellitus, and kidney disease in Michigan: a standardized mortality ratio analysis. Environmental Health. 200761:1-11.

21. Rahman A, Vahter M, Ekström EC, Rahman M, Golam Mustafa AHM, Wahed MA, et al. Association of arsenic exposure during pregnancy with fetal loss and infant death: a cohort study in Bangladesh. American journal of epidemiology. 200716512:1389.

22. Milton AH, Smith W, Rahman B, Hasan Z, Kulsum U, Dear K, et al. Chronic arsenic exposure and adverse pregnancy outcomes in Bangladesh. Epidemiology. 2005161:82-6.

23. Thakur JS, Prinja S, Singh D, Rajwanshi A, Prasad R, Parwana HK, et al. Adverse reproductive and child health outcomes among people living near highly toxic waste water drains in Punjab, India. BMJ journal. 2009642:148-54.

24. Gerhard I, Waibel S, Daniel V, Runnebaum B. Impact of heavy metals on hormonal and immunological factors in women with repeated miscarriages. Human Reproduction Update. 199843:301.

25. Hauke KP, Lora F, Lorraine B, Elaine F, Porter $\mathrm{H}$, Ami T, et al. Linking the oceans to public health: current efforts and future directions. Environmental Health: A Global Access Science Source. 20087.

26. McCarver. Chemical Found in Crude Oil Linked to Congenital Heart Disease: Fetal Exposure to Solvents May Damage Heart. ScienceDaily; 2011 [cited 2011 Sep 20]; Available from: http://www.sciencedaily.com/ releases/2011/04/110430133127.htm.

27. O'Hanlon L. Children at Greatest Risk From Oil Spill. Discovery News; 2010 [cited 2010 20th of December]; Available from: http://news. discovery. com/human/children-gulf-oil-hazards.html.

28. Venkatachalapathy R, Veerasingam S, Ramkumar T. Petroleum hydrocarbon concentrations in marine sediments along Chennai Coast, Bay of Bengal, India.Bull Environ Contam Toxicol. 2010 Oct;854:397-401.

29. MoWR. Coastal Development Strategy. In: Resources MoW, editor. Dhaka: WARPO; 2006.

30. CAPTA. The Child Abuse Prevention and Treatment Act Including Adoption Opportunities \& The Abandoned Infants Assistance Act. U.S. Department of Health and Human Services; 2010 [cited 201120 Sep]; Available from: www.acf.hhs.gov/programs/cb/laws.../capta2010.pdf

31. Samarakoon J. Issues of livelihood, sustainable development, and governance: Bay of Bengal. Ambio. 2004331:34-44.

32. Kaly UL. Review of Land-based sources of pollution to the coastal and marine environments in the BOBLME Region theme report: Bay of Bengal Large Marine Ecosystem (BOBLME)2004 Contract No.: GCP/RAS/179/ WBG.10 FAO-BOBLME Programme. 
33. Staples D. Transboundary Diagnostic Analysis of the Bay of Bengal Large Marine Ecosystem: BOBLME, FAO2010.

34. Ramesh R, Nammalwar P, Gowri VS. Database on Coastal Information of Tamil Nadu. Chennai: Institute for Ocean Management Anna University Chennai 2008.

35. Siddiquee NA, Parween S, Quddus MMA, Barua P. Heavy Metal Pollution in Sediments at Ship Breaking Area of Bangladesh. 2009.

36. Mashreque DMS. Workers in Shipbreaking Industries: A Base Line Survey of Chittagong (Bangladesh). Chittagong: Google book; 2005

37. Sarraf $M$, Stuer-Lauridsen F, Dyoulgerov $M$, Bloch $R$, Wingfield $S$, Watkinson R. Ship Breaking and Recycling Industry in Bangladesh and Pakistan: World Bank2010 Contract No.: 58275.

38. Agrawala S, Ota T, Ahmed AU, Smith J, van Aalst M. Development and climate change in Bangladesh: focus on coastal flooding and the Sundarbans. OCDE (Organización de Cooperación y Desarrollo Económicos), París.2003.

39. MoEF. Bangladesh: National Programme of Action for Protection of the Coastal and Marine Environment from Land-Based Activities. Dhaka: Ministry of Environment and Forest; 2004 [cited 2010 Oct 13]; Available from: www.doe-bd.org/npa_draft.pdf

40. Asian Development Bank \& Bangladesh: Factsheet [database on the Internet]. Asian Development Bank. 2009 [cited 12th March 2010]. Available from: www.adb.org/Documents/Fact_Sheets/BAN.pdf

41. Asian Development Bank [database on the Internet]2004.

42. Agustina $\mathrm{H}$. Indonesia country report: Land based sources of Marine Pollution. Jakarta: BOBLME2011.
43. BMD. List of Major Cyclonic Storms from 1960 to 2009 which caused huge loss of lives \& properties in Bangladesh. Dhaka: Bangladesh Meteorological Department2010.

44. Fakhruddin SHM. Standard operation procedures for Disaster Managment [Report]. In press 2010

45. Titumir RAM, Hossain J. Disability in Bangladesh. Dhaka: Handicap International \& National Forum of Organizations Working with the Disabled(NFOWD) 2005.

46. Tabib SMSB. Prevalence of childhood disabilities and cerebral palsy in the community. 2009.

47. Haseen F. Nutritional Situation and Related Factors in $\mathrm{MNCH}$ Project Area at Baseline. 2006.

48. Planning Commission GoB, UNDP Bangladesh. A Situation Analysis Report on Health (MDG 4,5 and 6) Bangladesh. 2010.

49. BDHS. Bangladesh Demographic and Health Survey2007.

50. Hussain M, Hoq ME. Marine and coastal resources of Bangladesh: BOBLME project implication. Chittagang: BOBLME; 2010 [cited 2011 3rd February]; Available from: m.iwlearn.net/iw-projects/1252/repo....

51. Trasande L, Landrigan PJ, Schechter C. Public Health and Economic Consequences of Methyl Mercury Toxicity to the Developing Brain. Environmental Health Perspectives. [Article]. 20051135:590-6.

52. Shuval H. Estimating the global burden of thalassogenic diseases: human infectious diseases caused by wastewater pollution of the marine environment. Journal of Water and Health. 200312:53-64.

53. PDO-ICZMP. Profile of the coastal zone of Bangladesh: Human Conditions. Dhaka: WARPO; 2003. 